\title{
Extrusion pretreatment of maize straw - case study for a Polish biogas plants
}

\author{
Kamil Kozłowski ${ }^{1 *}$, Andrzej Lewicki ${ }^{1}$, Wojciech Czekała ${ }^{1}$, Agnieszka Wótowicz ${ }^{2}$, \\ Karol Kupryaniuk ${ }^{2}$, and Danuta Dróżdż

\begin{abstract}
${ }^{1}$ Institute of Biosystems Engineering, Poznań University of Life Science, Wojska Polskiego 28, 60-637 Poznań, Poland ${ }^{2}$ Department of Thermal Technology and Food Process Engineering, Lublin University of Life Sciences, Doświadczalna 44, 20-280 Lublin, Poland
\end{abstract} \\ ${ }^{3}$ Institute of Environmental Engineering, Częstochowa University of Technology, Brzeźnicka 60A, 42-201 Częstochowa, Poland
}

Received September 16, 2018; accepted May 22, 2019

\begin{abstract}
One of the most commonly used substrates in biogas plants is maize silage, however, the application of monofermentation technology under Polish economic conditions has a tendency to rapidly bankrupt the investor. The lack of profitability of investments based on this material has encouraged investors to search for other, more economically favourable biomass sources i.e. maize straw. The aim of the research was to compare the energetic potential of untreated maize straw and extruded maize straw used for biogas production and furthermore, to determine the amount of electricity and heat generated as well as the amount of heat produced from direct combustion. The results obtained confirmed the substantial energy potential of maize straw. It has been proven that using the extrusion method as a pretreatment before the fermentation process, enables the producer to increase biogas and methane production respectively by 7.50 and $8.51 \%$. However, the use of an extruder machine in biogas plants in Poland is economically unjustified due to its high energy consumption. Moreover, it has been shown, that the use of maize straw in the methane fermentation process enables it to generate (in Poland) a higher income than is the case of using this material in a direct combustion process.
\end{abstract}

Keywords: maize straw, extrusion, methane fermentation, biogas, energetic potential

\section{INTRODUCTION}

Climate change and the potent emissions of pollution generated from conventional electricity and heat production systems, have resulted in the use of an increased share of renewable energy sources (RES) in the national ener-

*Corresponding author e-mail: kamil.kozlowski@up.poznan.pl getic systems and in transport (Mesarić and Krajcar, 2015; Zhang et al., 2010). These changes have become especially noticeable in the last decade (Borenstein, 2015).

The need to change the direction of current energy policy has significantly influenced the development of new environmentally friendly technologies (Caceres et al., 2015; Papadias et al., 2012; Parpurello et al., 2015). One of the methods proposed to fulfil the targets set by the European Union, is to use a biomass for energy generation purposes (Czekała et al., 2015; Dach et al., 2014; Igliński et al., 2012; Lewicki et al., 2014). This is mainly due to the large area of agricultural land (approx. 14.6 million ha) (Central Statistical Office, 2016) along with well-developed cattle and swine breeding as well as poultry farming (Piwowar $e t$ al., 2016). However, due to the high price of maize silage (approx. $30 \mathrm{EUR} \mathrm{Mg}^{-1}$ fresh matter) (Dach et al., 2014), the risk related to monoculture cultivation and the low level of financial support from the government (compared with RES support in Germany), potential biogas investors are looking for alternative substrates which may be used in energy production (Dach et al., 2014). One very important reason for the positive economic balance of investment (in Poland) is also the implementation of innovative technologies, the use of the heat produced in heat and power co-generation $(C H P)$ and the management of digested pulp, as a high quality organic fertilizer (Czekała et al., 2012, 2015; Dach et al., 2014).

(C) 2019 Institute of Agrophysics, Polish Academy of Sciences 
In the last few years, there has been a notable increase in the use of non-food materials and agricultural waste for energy production (White et al., 2013). This is related to the low cost of purchase resulting in an increase in the economic profitability of the potential investment. One of these materials is maize straw, which has a lower cost in the range of 12-17 EUR $\mathrm{Mg}^{-1} \mathrm{FM}$ than maize silage and is characterized by a high methane yield (Mo and Pilarski, 2011). Moreover, this substrate does not have a wider application in Polish agriculture and industry (Przybył et al., 2013). Maize straw usually remains in the fields as a crop residue.

It is also worth noting that the pretreatment of the substrate before anaerobic digestion is becoming more frequent. This allows for an increase in the efficiency of biogas production, especially from lignocellulosic substrates resistant to decomposition (Rafique et al., 2010; Zhang et al., 2016). There are four kinds of pretreatments: physical (using high temperature and pressure) (Ahring et al., 2015; Kratky and Jirout, 2015; Ruffino et al., 2015; Tedesco et al., 2016; Theuretzbacher et al., 2015b), chemical (with the use of acids or alkali) (Gu et al.,2015; Li et al., 2015; Liu et al., 2015), biological (i.e. the application of appropriate bacterial consortia or fungi and yeast) and mixed (a combination of physical, chemical and biological treatments) (Lamsal et al., 2010; Reilly et al., 2015; Theuretzbacher et al., 2015a). Currently, in Poland the most popular choice is the mechanical pretreatment of the substrate material. One possible solution may be the use of extrusion in order to increase the biogas production efficiency of the substrate. This technology is commonly used in other branches of industry i.e. food industry, plastics and/or metals moulding (Rodriguez et al., 2017), and the devices are widely available (Lehmann Maschinenbau, 2012).

In the extrusion process, the substrate is heated, mixed and pulverized, which causes the lignin and cellulose fibres to break apart. Furthermore, the sudden decrease in pressure causes the evaporation of intracellular water, which additionally increases the efficiency of the disintegration of the material (Lehmann Maschinenbau, 2012).

The research aim was to define and compare the energy potential of the untreated maize straw and extruded maize straw used in biogas production (for electricity and heat generation) as well as heat from direct combustion. The range of research experiments included the determination of the physicochemical parameters the substrates used and research into the methane fermentation of untreated maize straw and extruded maize straw. In addition, the heat of combustion and the calorific value of the tested materials were determined. The revenue per $\mathrm{Mg}$ of substrate used for biogas and biomass boiler utilization was also estimated, taking into account the national RES support scheme.

\section{MATERIALS AND METHODS}

The maize straw used in the research experiments was obtained from Przybroda Agricultural-Orchard Experimental Farm belonging to the Poznan University of Life Sciences (PULS). The fermentative inoculum was the separated liquid fraction (after dry mass separator) taken from the operating agricultural biogas plant in Działyń (Poland).

In order to select the appropriate proportions between the tested substrate and inoculum, the following parameters were examined: total solids (TS) - PN-75 C-04616/01, volatile total solids (VS) - PN-Z-15011-3, pH PN-90 $\mathrm{C}-04540 / 01$. These parameters enabled the subsequent calculation of biogas efficiency calculated based on the $\mathrm{Mg}$ of fresh matter, total solids and volatile total solids of the substrate.

The pretreatment of the tested material was carried out in the Department of Thermal Technology and Food Process Engineering at the University of Life Sciences in Lublin. In the experiment, a device made by the staff of the Department was used. The material was treated at a temperature of $140^{\circ} \mathrm{C}$ and high pressure. The rotation speed of the screw conveyor set at $70 \mathrm{rpm}$. The extruder was driven by a $10 \mathrm{~kW}$ motor. The starting humidity of the tested material was set at a level of $25 \%$. Samples $(2 \mathrm{~kg})$ were collected from the exit of the extruder at the outlet opening. Control and treated samples were collected in plastic (polyethylene) containers and stored at $4^{\circ} \mathrm{C}$ until analysis.

The research concerning the methane efficiency of the substrates in batch culture technology was carried out in the Laboratory of Ecotechnologies at the Institute of Biosystems Engineering (PULS) on the basis of internal procedures, based on adapted standards: DIN 38 414-S8 and VDI 4630, commonly used in Europe. The detailed methodology of the performed research was presented by Cieślik et al. (2016). The fermentation set-up consisted of 21 biofermentors. Each individual biofermentor (made from glass) had a volume of $1.8 \mathrm{dm}^{3}$. The process was carried out under mesophilic conditions at $39 \pm 1^{\circ} \mathrm{C}$. The biogas produced in each fermentor chamber was transported via teflon pipe to the gas storage system (volume $4 \mathrm{dm}^{3}$ ). These reservoirs were made from plexiglass as an inverted cylinder immersed in water. Between the water and gas areas, there was a liquid barrier preventing the dissolution of $\mathrm{CO}_{2}$ in the water. The volume of biogas produced was read at equally spaced 24-h intervals. The tested gases were methane, carbon dioxide, ammonia, hydrogen sulphide and oxygen as a control, and the results were recorded with an accuracy of $0.01 \mathrm{dm}^{3}$. Measurements were made using Geotech's GA5000 certified gas analyser (certificates ATEX II 2G Ex ib IIA T1 $\mathrm{Gb}\left(\mathrm{Ta}=-10^{\circ} \mathrm{C}\right.$ do $\left.+50^{\circ} \mathrm{C}\right)$, CSA certificates and UKAS ISO 17025 calibration). The ranges of gases detected by the analyser were: $0-100 \% \mathrm{CH}_{4}, 0-100 \% \mathrm{CO}_{2}, 0-25 \%$ $\mathrm{O}_{2}, 0-10000$ ppm $\mathrm{H}_{2} \mathrm{~S}$ and 0-1 000 ppm $\mathrm{NH}_{3}$. 
The research concerning the heat of combustion was carried out in the Section of Wood Chemistry and Forest Products at Poznan University of Life Sciences according to Polish norm PN-81/G-04513. Based on literature data, the heat of combustion was calculated, taking into account the hydrogen content at a level of 5.3\% (Herkowiak et al., 2018; Kołodziej and Matyka, 2012). The substrate was fragmented, next three 1-gram samples were taken, in order to define the heat of combustion using calorimeter KL-12Mn.

The heat of combustion and the calorific value of the tested fuels were determined using the calorimeter method. The measurement of the heat of combustion was based on the complete combustion of the substrate sample placed in a calorimeter bomb immersed in water. Measurement was performed under clean oxygen conditions. The calorific value (by calorimetric method) was determined in accordance with PN-81/G-04513. Using formulas (1) and (2) the parameter values were determined (Czekała et al., 2018):

$$
Q_{s}^{a}=\frac{C\left(D_{t}-k\right)-c}{m},
$$

where: $Q_{s}^{a}$ - average calorific value of the fuel analysed $\left(\mathrm{J} \mathrm{g}^{-1}\right), C$-heat capacity of the calorimeter $\left(\mathrm{J} \mathrm{g}^{-1}\right), D_{t}$ - overall increase of the main period temperature $(\mathrm{K}), k$ - correction for environmental heat exchange $(\mathrm{K}), c$ - correction sum for the additional heat effects $(\mathrm{J}), m$ - fuel sample mass $(\mathrm{g})$.

Calorific value $\left(Q_{w}\right)$ in the analytical state was calculated using the following equation:

$$
Q_{w}^{a}=Q_{s}^{a}-24.42^{(1)}\left(W^{a}+8.94^{(2)} H_{a}\right),
$$

where: $Q_{w}^{a}$ - calorific value of the analysed biofuels in the analytical state $\left(\mathrm{J} \mathrm{g}^{-1}\right), W^{a}$ - moisture content of the test sample (\%), $H_{a}$ - hydrogen content of the test sample (\%), ${ }^{1}$ heat of evaporation of water at temperature $25^{\circ} \mathrm{C}$, which corresponds to $1 \%$ of the water in the fuel $\left(\mathrm{J} \mathrm{kg}^{-1}\right),{ }^{2}$ factor of hydrogen to water conversion (-).

Knowing the methane volume that may be obtained from $1 \mathrm{Mg}$ of the substrate, it is possible to calculate the amount of obtainable electricity and heat. Therefore, in order to calculate the amount of energy produced, it is necessary to introduce a methane calorific value of 0.009968 MWh m${ }^{-3}\left(9.968 \mathrm{kWh} \mathrm{m}^{-3}\right)$. Expression of the efficiency factor in MWh is due to the fact that the megawatt hour is a basic unit of settlement of the RES energy producers in Poland. The relevant formulas are given below.

The amount of electricity produced in the co-generation of heat and power (CHP) may be calculated by the following equation:

$$
E_{E}=V_{\mathrm{CH}_{4}} W e_{\mathrm{CH}_{4}} \eta_{e}
$$

where: $E_{E}$ - amount of electricity produced in CHP (MWh $\left.\mathrm{Mg}^{-1} \mathrm{FM}\right), V_{\mathrm{CH}_{4}}$ - produced methane volume $\left(\mathrm{m}^{3} \mathrm{Mg}^{-1} \mathrm{FM}\right)$, $W e_{C_{4}}-$ methane calorific value $\left(0.009968 \mathrm{MWh} \mathrm{m}^{-3}\right), \eta_{\mathrm{e}}-$ electrical efficiency of co-generation unit (for the purposes of these calculations $42 \%$ efficiency was assumed for the unit offered by PAKTOMA, Polish manufacturer of modern co-generation units for biogas plants).

Amount of heat produced in CHP was calculated in accordance with the following equation:

$$
E_{\mathrm{H}(\mathrm{CHP})}=V_{\mathrm{CH}_{4}} W e_{\mathrm{CH}_{4}} \eta_{t(\mathrm{CHP})},
$$

where: $E_{H(C H P)}$ - amount of heat produced in $C H P(\mathrm{MWh}$ $\left.\mathrm{Mg}^{-1} \mathrm{FM}\right), \eta_{t(C H P)}$ - heat efficiency of co-generation unit (for the purposes of these calculations $45 \%$ efficiency was assumed for the unit offered by PAKTOMA, Polish manufacturer of modern co-generation units for biogas plants).

In practice, the amount of heat produced is given in gigajoules (GJ). Knowing that $1 \mathrm{GJ}$ equals $0.274 \mathrm{MWh}$, the generated heat expressed in MWh can be converted according to the following equation:

$$
E_{H(C H P)_{(G J)}}=\frac{E_{H(C H P)}}{0.274},
$$

where: $E_{H(C H P)_{(\mathrm{GJ} J}}-$ amount of heat produced in $C H P$ (GJ $\left.\mathrm{Mg}^{-1} \mathrm{FM}\right)$.

The amount of heat produced in the direct combustion of the substrate is shown by Eqs (6) and (7):

$$
E_{H D_{(G J)}}=C_{V} \eta_{t(s)},
$$

where: $E_{H D_{(\mathrm{G})}}-$ amount of heat produced in direct combustion (GJ $\left.\mathrm{Mg}^{-1} \mathrm{FM}\right), C_{v}$ - calorific value (GJ $\left.\mathrm{Mg}^{-1} \mathrm{FM}\right), \eta_{t(s)}$ - heat efficiency of stove (-) (for the purposes of these calculations $85 \%$ efficiency was assumed for the unit offered by PAKTOMA, Polish manufacturer of modern co-generation units for biogas plants).

$$
E_{H D(M W h)}=E_{H D_{(G J)}} 0.274,
$$

where: $E_{H D(M W h)}-$ amount of heat produced in direct combustion ( $\mathrm{MWh} \mathrm{Mg}^{-1} \mathrm{FM}$ ).

In the economic calculations, two systems (resulting from the amendment of the Renewable Energy Act of 22 June 2016) supporting the production of renewable energy in agricultural biogas plants were included. For these installations, support is provided in the form of so-called "blue certificates" obtainable due to the production of $1 \mathrm{MWh}$. This type of certificate of origin is listed on the Polish Power Exchange, and its price depends on the supply and demand of energy produced in such installations. According to the data of the Polish Power Exchange of 31.01.2018 the "blue certificate" price was 76.44 EUR MWh $^{-1}$ (Polish Power Exchange, 2017). In addition, agricultural biogas plants in Poland can receive support for energy production in highefficiency co-generation (yellow certificate - 27.68 EUR $\mathrm{MWh}^{-1}$ ) for the sale of "black energy" (approx. 40.4 EUR $\mathrm{MWh}^{-1}$ ) and for the sale of heat produced (approx. 6.0 EUR $\mathrm{GJ}^{-1}$ ) (Table 1). It should be added that the sale price of "black energy" applies to the amount of electricity generated in co-generation. This price is announced quarterly by 
Table 1. Prices EUR of certificate of origin and heat as determined by the Polish Power Exchange and Energy Regulator Office of 31 January, 2018 (Energy Regulatory Office, 2017; Energy Regulatory Office, 2018; Polish Power Exchange, 2017)

\begin{tabular}{lcc}
\hline Parameter & Price & Unit \\
\hline Electricity price & 40.41 & EUR MWh $^{-1}$ \\
Blue certificate price & 76.44 & EUR MWh $^{-1}$ \\
Yellow certificate price & 27.68 & EUR MWh $^{-1}$ \\
Heat price & 6.02 & EUR GJ $^{-1}$ \\
Euro exchange rate & 4.1541 & PLN \\
\hline
\end{tabular}

the Energy Regulatory Office. The profit from the sale of electricity and heat produced in the co-generation from 1 Mg FM of the substrate was calculated as follows:

$$
I_{T C}=I_{E}+I_{H},
$$

where: $I_{T C}$ - total income from the certified electricity and heat sale (EUR $\left.\mathrm{Mg}^{-1} \mathrm{FM}\right), I_{E}$ - income from the electricity sale (EUR $\mathrm{Mg}^{-1} \mathrm{FM}$ ), $I_{H}$ - income from the heat sale (EUR $\left.\mathrm{Mg}^{-1} \mathrm{FM}\right)$.

The income generated from the sale of electricity depends on the amount of energy produced (reduced by $5 \%$ of the plant's own consumption), electricity sales prices and green and yellow certificates. The income from the sale of electricity may be calculated from Eqs (9) and (10):

$$
I_{E}=\left(\left(E_{E} 0.95\right)-E_{E X}\right) S P_{E},
$$

where: $E_{E}$ - amount of electricity produced in $C H P$ (MWh $\left.\mathrm{Mg}^{-1} \mathrm{FM}\right), E_{E X}$ - energy consumed for the work of the extruder (MWh $\left.\mathrm{Mg}^{-1} \mathrm{FM}\right), S P_{E}$ - electricity selling price $\left(\right.$ EUR $\left.\mathrm{MWh}^{-1}\right), 0.95$ - electricity sales ratio reduced by the amount of energy used for the needs of the installation itself.

$$
S P_{E}=S P_{B E}+S P_{B C}+S P_{Y C},
$$

where: $S P_{B E}$ - "black energy" price $\left(E U R \mathrm{MWh}^{-1}\right), S P_{B C}$ - "blue certificate" price (EUR $\left.M \mathrm{Mh}^{-1}\right), S P_{Y C}-$ "yellow certificate" price (EUR MWh ${ }^{-1}$ ).

Revenue generated from the sale of heat produced by the combustion of biogas may be estimated from the following equation:

$$
I_{H}=E_{H(C H P)_{(G J)}} S P_{H} 0.80,
$$

where: $I_{H}$ - income from the heat sale (EUR $\mathrm{Mg}^{-1} \mathrm{FM}$ ), $E_{H(C H P)_{(\mathrm{GJ})}}$ - amount of heat produced in CHP $\left(\mathrm{GJ} \mathrm{Mg}^{-1} \mathrm{FM}\right)$, $S P_{H}$ - selling price of heat $\left(E U R G^{-1}\right), 0.80$ - heat sales ratio reduced by the amount of heat used for own demands of the installation under mesophilic technology (Oleszek et al., 2016).
The reform of the RES support system in Poland envisages auctions for the purchase of a specified amount of energy, by the Polish government, for renewable energy producers. The winners of the auction offering the lowest selling price for electricity, will be guaranteed a15-year contract from the auction date. Additionally, Polish law has included provisions for the separation of auctions for energy produced from certain types of renewable energy sources, i.e. for producers using only agricultural biogas. Moreover, separate categories for installations below or over $1 \mathrm{MV}$ capacity have been included. The new support system for agricultural biogas energy ensures that the reference price (i.e. the maximum price for $1 \mathrm{MWh}$, for which the generated electricity can be sold by the producers) from RES in 2016-2018 for installations using only agricultural biogas will be not less than $129.70 \mathrm{EUR}_{\mathrm{MWh}} \mathrm{MW}^{-1}$. Accordingly, the total income from the sale of electricity and heat produced in co-generation in the auction system can be calculated according to Eq. (12):

$$
I_{T A}=\left(\left(E_{E} 0.95\right)-E_{E X}\right) C_{R},
$$

where: $I_{T A}$ - total income from the electricity and heat sold in the auction system (EUR $\left.\mathrm{Mg}^{-1} \mathrm{FM}\right), C_{R}$ - reference price $\left(E U R \mathrm{MWh}^{-1}\right), 0.95$ - electricity sales ratio reduced by the amount of energy used for the needs of the installation itself.

At present, it is difficult to predict what price for 1 MWh of energy will be offered to owners of agricultural biogas plants in the conducted auctions. For this reason, the reference price was used for the economic calculation as the selling price of the electricity.

In the case of using maize straw in the direct combustion process in a specially adapted oven, it is possible to obtain additional income from the sale of heat to the district heating network. This parameter is calculated from the following equation:

$$
I_{H(D C)}=E_{H D_{(G J)}} S P_{H},
$$

where: $I_{H(D C)}-$ total income from the sale of heat produced by direct straw combustion (EUR $\mathrm{Mg}^{-1} \mathrm{FM}$ ).

\section{RESULTS AND DISCUSSION}

The basic physical and chemical parameters, which are necessary to estimate the energetic potential of the substrate were: $\mathrm{pH}$, total solids and volatile solids content.

Untreated and extruded maize straw were characterized by a high TS and VS content of 92.80 and $93.67 \%$, as well as 89.20 and $95.42 \%$, respectively (Table 2 ).

The methane fermentation process of untreated maize straw under mesophilic conditions was performed for 34 days (Fig. 1). It is worth emphasizing that in the case of technologies commonly implemented in biogas plants, which use maize silage as the main substrate, the process is 
Table 2. Physical and chemical parameters of inoculum and extruded and untreated maize straw

\begin{tabular}{lcccc}
\hline Sample & $\mathrm{pH}$ & $\begin{array}{c}\text { Total solids (TS) } \\
(\% \text { FM) }\end{array}$ & $\begin{array}{c}\text { Volatile total solids (VS) } \\
(\% \text { TS })\end{array}$ & References \\
\hline Inoculum & 7.85 & $2.80 \pm 0.027$ & $71.02 \pm 1.778$ & $(-)$ \\
Untreated maize straw & 9.55 & $92.80 \pm 0.339$ & $89.20 \pm 1.376$ & $(-)$ \\
Extruded maize straw & 6.37 & $93.67 \pm 0.214$ & $95.42 \pm 0.117$ & $(-)$ \\
Maize silage & 3.77 & 37.24 & 90.79 & $($ Li et al., 2015) \\
\hline
\end{tabular}

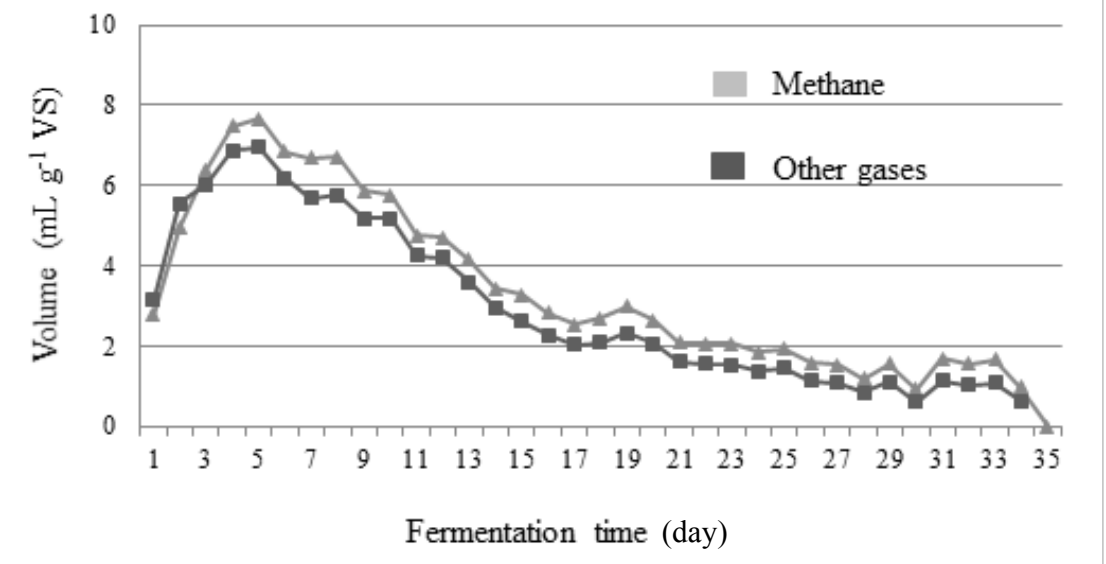

Fig. 1. Daily dynamics of biogas production for tested untreated maize straw in the methane fermentation process.

similar - about 35 days (Dach et al., 2014). The long duration of maize straw decomposition is due to the complex structural composition of the substrate (McKendry, 2002; Zheng et al., 2014). It is characterized by a high content of tightly bounded lignin and cellulose fibres, which are difficult for microorganisms to consume, and a small share of simple sugars and starch (Cieślik et al., 2016; Irlbeck et al., 1993; Russell, 1986). Figure 1 shows the daily dynamics of biogas production for tested untreated maize straw.

During the methane fermentation process of untreated maize straw (Fig. 1) notable peaks of biogas production were observed (between the 3rd and 6th day of fermentation), which were the result of the fermentation of small amounts of easily accessible carbohydrates. Also, in view of the packed structure and high degree of polymerization, the biodegradation process is characterized by a long duration (Cieślik et al., 2016; McKendry, 2002; Mosier et al., 2005; Zhang et al., 2010). Figure 2 shows the change in the daily dynamics of biogas and methane production from extruded maize straw.

In the case of the fermentation of extruded maize straw, the intensive production of biogas during the first 9 days of the process was observed (Fig. 2). The change in the daily dynamics of biogas production for the tested extruded maize straw, compared to the untreated sample, results from cellulose, hemicellulose, lignin and protein depolymerization in the substrate (Camire, 1998; Karunanithy and Muthukumarappan, 2010). Additionally, the fragmentation of the material allowed for an increase in the area available for fermentation bacteria, and this resulted in an improvement of the efficiency of the hydrolysis and methanogenesis process (Bougrier et al., 2006; Hjorth et al., 2011).

The investigated maize straw was characterized by a relatively high biogas efficiency at the level of $407.75 \mathrm{~m}^{3} \mathrm{Mg}^{-1}$ FM, due to the low humidity of the substrate (Table 3 ). This result is comparable with the results of other research experiments related to maize straw fermentation (Cieślik et al., 2016; Lewicki et al., 2014). In the case of the use of substrate extrusion, an increase in biogas and methane production was observed, by 7.50 and $8.51 \%$ respectively. This study confirmed the results obtained by Hjorn et al. (2011) and Brückner et al. (2007), which proved that using extrusion for agricultural substrates (e.g. maize straw) as a pretreatment before the fermentation process, can increase methane efficiency from 8 up to $70 \%$. The percentage of methane content in the gas produced was about $51 \%$, which is characteristic for substrates with a high share of the carbohydrates fraction.

One of the most important parameters, which are characteristic for materials with potential energy applications, is combustion heat. This parameter determines the amount of heat emitted during the combustion of a fuel mass unit in an oxygen atmosphere, with the assumption that the end products are oxygen, nitrogen, carbon dioxide, sulphur oxides, water in a liquid state and ash. The second parameter is the calorific value reduced by the amount of heat, which is required for water evaporation. Comparing these two results, produces information about the possible energy 


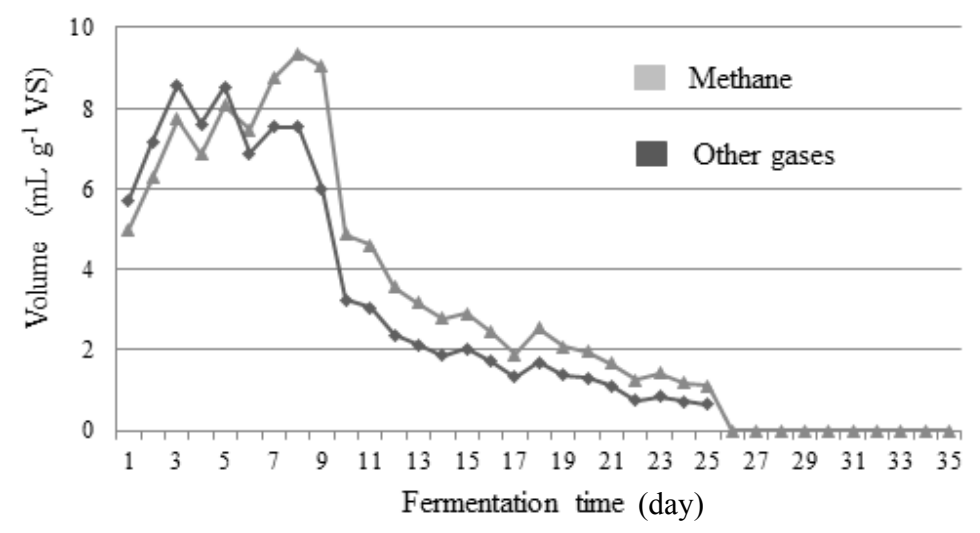

Fig. 2. Daily dynamics of biogas production for tested extruded maize straw in the methane fermentation process.

Table 3. Biogas efficiency of maize straw in mesophilic fermentation

\begin{tabular}{lcccccc}
\hline & \multicolumn{2}{c}{ Fresh matter } & \multicolumn{2}{c}{ Volatile solids } & \\
\cline { 2 - 5 } Sample & \multicolumn{2}{c}{$\begin{array}{c}\text { Cumulated } \\
\text { methane }\end{array}$} & Cumulated biogas & $\begin{array}{c}\text { Cumulated } \\
\text { methane }\end{array}$ & Cumulated biogas & References \\
\cline { 2 - 5 } Untreated maize straw & $207.75 \pm 7.14$ & $407.81 \pm 16.55$ & $237.30 \pm 10.23$ & $465.82 \pm 23.70$ & $(-)$ \\
Extruded maize straw & $225.42 \pm 4.14$ & $438.40 \pm 9.63$ & $252.47 \pm 4.88$ & $491.00 \pm 11.35$ & $(-)$ \\
Maize silage & 130.88 & 218.40 & 387.10 & 645.96 & (Li et al., 2015) \\
\hline
\end{tabular}

yield calculated per unit mass of the substrate. The following Table 4 shows results of combustion heat and calorific value analyses of maize straw.

The untreated maize straw used in research, was characterized by a heat of combustion and calorific value respectively at the levels 16.90 and $15.58 \mathrm{MJ} \mathrm{g}^{-1} \mathrm{FM}$ (Table 4). These values are comparable with results, which were obtained by other researchers. According to McKendry (2002), the heat of combustion of the substrate is heavily dependent on the moisture content. According to Mani et al. (2004) during research concerning the energy efficiency of maize with a moisture content of approx. $9.41 \%$, the results indicated a calorific value with a level of approx. $16.2 \mathrm{MJ} \mathrm{kg}^{-1} \mathrm{FM}$.

On the basis of the results obtained for the biogas efficiency and calorific value of maize straw, an economic analysis of the profitability of the development of this substrate for energy purposes on the Polish market was conducted. On the basis of the existing system based on certificates of origin and an auction system, the income obtained from methane fermentation or direct incineration was calculated (Table 5).

Based on this calculation, it is apparent that the maize straw extrusion process prior to the fermentation process results in an increase of electricity production by $8.51 \%$ from $1 \mathrm{t}$ of the substrate. This is due to the increased methane yield from the methane fermentation process, as demonstrated by other researchers and described in a previous section (Hjorth et al., 2011). In the currently operating systems supporting the production of energy from agricultural biogas in Poland, the extrusion of maize straw may be economically unjustified due to the high energy consumption of the extruder $\left(0.492 \mathrm{MWh} \mathrm{Mg}^{-1} \mathrm{FM}\right)$. The use of this kind of substrate pretreatment results in a decrease of total income from the sale of electricity and heat by 59.56 EUR $\mathrm{Mg}^{-1} \mathrm{FM}$ (for the system of certificates of origin) and 54.44 EUR $\mathrm{Mg}^{-1} \mathrm{FM}$ (in the case of the auction system) (Table 5).

Table 4. Heat of combustion and calorific value of maize straw

\begin{tabular}{cccc}
\hline Substrate & $\begin{array}{c}\text { Moisture content } \\
(\%)\end{array}$ & $\begin{array}{c}\text { Heat of combustion } \\
\left(\mathrm{J} \mathrm{g}^{-1}\right)\end{array}$ & $\begin{array}{c}\text { Calorific value } \\
\left(\mathrm{J} \mathrm{g}^{-1}\right)\end{array}$ \\
\hline Untreated maize straw & $7.20 \pm 0.339$ & $16900 \pm 330$ & $15567 \pm 255$ \\
\hline
\end{tabular}


Table 5. Possible income from the sale of electricity and heat produced from $1 \mathrm{Mg}$ of fresh maize straw

\begin{tabular}{|c|c|c|c|c|c|}
\hline \multirow{3}{*}{ Parameters } & \multicolumn{4}{|c|}{ Methane fermentation } & \multirow[t]{2}{*}{ Direct combustion } \\
\hline & \multicolumn{4}{|c|}{ Maize straw } & \\
\hline & \multicolumn{2}{|l|}{ Untreated } & \multicolumn{2}{|l|}{ Extruded } & \multirow[t]{2}{*}{ Untreated } \\
\hline & & Electricity a & heat & & \\
\hline Electricity (MWh $\mathrm{Mg}^{-1}$ ) & 0.870 & & 0.944 & & - \\
\hline Heat $\left(\mathrm{MWh} \mathrm{Mg}^{-1}\right)$ & 0.932 & & 1.011 & & 3.575 \\
\hline Heat $\left(\mathrm{GJ} \mathrm{Mg}^{-1}\right)$ & 3.401 & & 3.690 & & 13.048 \\
\hline \multirow[t]{3}{*}{$\begin{array}{l}\text { Extrusion } \\
\text { energy consumption }\left(\mathrm{MWh} \mathrm{Mg}^{-1}\right)\end{array}$} & - & & 0.492 & & - \\
\hline & \multicolumn{4}{|c|}{ Income } & \\
\hline & $\begin{array}{l}\text { Certificate of } \\
\text { origin system }\end{array}$ & Auction system & $\begin{array}{l}\text { Certificate of } \\
\text { origin system }\end{array}$ & $\begin{array}{l}\text { Auction } \\
\text { system }\end{array}$ & $\begin{array}{c}\text { Sale } \\
\text { in both } \\
\text { systems }\end{array}$ \\
\hline Electricity $\left(\mathrm{EUR} \mathrm{Mg}^{-1}\right)$ & 33.39 & - & 16.35 & - & - \\
\hline Blue certificate (EUR $\mathrm{Mg}^{-1}$ ) & 63.16 & - & 30.92 & - & - \\
\hline Yellow certificate $\left(\mathrm{EUR} \mathrm{Mg}^{-1}\right)$ & 22.87 & - & 11.20 & - & - \\
\hline Auction (EUR Mg $\left.{ }^{-1}\right)$ & - & 109.40 & - & 56.82 & - \\
\hline Heat (EUR Mg $\left.{ }^{-1}\right)$ & 16.37 & 16.37 & 17.77 & 17.77 & 78.52 \\
\hline Amount (EUR Mg-1) & 135.80 & 125.77 & 76.24 & 71.33 & 78.52 \\
\hline
\end{tabular}

At the same time, it has been shown that under current conditions, it is more profitable for functioning biogas plants to retain the certificate of origin system, where the income from $1 \mathrm{Mg}$ of material for the installation is higher by approximately 5-10 EUR MWh${ }^{-1}$ than is the case for the auction system. However, it is important to bear in mind the volatility of the "blue certificates" price on the energy market, which depends on the supply and demand of electricity produced from agricultural biogas. In the case of winning the auction, the investor is guaranteed that the energy produced from agricultural biogas will be purchased at a fixed price for a period of 15 years, which in the longer term may prove to be a more advantageous solution.

The use of untreated maize straw in the direct combustion process seems to be economically unreasonable. The significantly higher income resulting from the utilization of the substrate for biogas is due to the possibility of selling heat and electricity. Increasing the calorific value of the straw by mechanically breaking up the material is associated with an additional cost of energy consumption, which may increase the difference in the income from $\mathrm{Mg}$ of the fresh weight.

\section{CONCLUSIONS}

1. Maize straw has a lower biogas potential (at the level $439.45 \mathrm{~m}^{3} \mathrm{Mg}^{-1} \mathrm{TS}$ ) in comparison with maize silage $\left(586.47 \mathrm{~m}^{3} \mathrm{Mg}^{-1} \mathrm{TS}\right)$ but it may be used as an alternative substrate in the methane fermentation process and as a fuel in biomass stoves.
2. The validity of using maize straw as a substrate in biogas plants was confirmed by a significantly higher income from the use of $1 \mathrm{Mg}$ of the material in contrast to its direct combustion.

3. Using the extrusion process for biogas substrates increases biogas and methane efficiency in the fermentation process by 7.50 and $8.51 \%$ respectively, and reduces fermentation time by approximately 8 days.

4. Despite the increased efficiency of the fermentation process, the use of extrusion in Poland is economically unjustified due to the high energy consumption of the pretreatment process.

5. Under current economic conditions prevailing in the market for renewable energy produced from biogas in Poland, the use of the certificate of origin system allows for the generation of a higher income from $1 \mathrm{Mg}$ of maize straw than is the case with the auction system.

Conflict of interest: The Authors declare they have no conflict of interest.

\section{REFERENCES}

Ahring B.K., Biswas R., Ahamed A., Teller P.J. and Uellendahl H., 2015. Making lignin accessible for anaerobic digestion by wet-explosion pretreatment. Bioresour. Technol., 175, 182-188. https://doi.org/10.1016/j.biortech.2014.10.082

Borenstein S., 2015. Is the Future of Electricity Generation really Distributed? Energy Inst. Haas. https://energyathaas.wordpress.com/2015/05/04/is-the-future-of-electricity-generation-really-distributed. Accessed 1 February 2018. 
Bougrier C., Delgenès J.P., and Carrere H., 2006. Combination of thermal treatments and anaerobic digestion to reduce sewage sludge quantity and improve biogas yield. Process Saf. Environ. Prot., 84, 4, 280-284. https://doi.org/10.1205/psep.05162

Brückner C., Weiss D., and Mildner U., 2007. Mundgerechtere bakterienkost. Bauern Ztg., 36, 48-49.

Caceres R., Coromina N., Malińska K., and Marfa O., 2015. Evolution of process control parameters during extended composting of green waste and solid fraction of cattle slurry to obtain growing media. Biores. Technol., 179, 398-406. https://doi.org/10.1016/j.biortech.2014.12.051

Camire M.E., 1998. Chemical changes during extrusion cooking: recent advances. In: Process-induced chemical changes in food (Eds F. Shahidi, C.-T. Ho, N. van Chuyen). New York Plenum Press.

https://doi.org/10.1007/978-1-4899-1925-0_11

Central Statistical Office of Poland, 2016. Agriculture in 2015. Warsaw, Poland. http://stat.gov.pl/en/topics/agriculture-forestry/agriculture/agriculture-in-2015,4,12.html

Cieślik M., Dach J., Lewicki A., Smurzyńska A., Janczak D., Pawlicka-Kaczorowska J., Boniecki P., Cyplik P., Czekała W., and Jóźwiakowski K., 2016. Methane fermentation of the maize straw silage under meso- and thermophilic conditions. Energy 115, 1495-1502. https://doi.org/10.1016/j.energy.2016.06.070

Czekala W., Bartnikowska S., Dach J., Janczak D., Smurzyńska A., Kozłowski K., Bugała A., Lewicki A., Cieślik M., Typańska D., and Mazurkiewicz J., 2018. The energy value and economic efficiency of solid biofuels produced from digestate and sawdust. Energy, 159, 11181122. https://doi.org/10.1016/j.energy.2018.06.090

Czekała W., Kozlowski K., Dach J., Boniecki P., Lewicki A., Janczak D., Jozwiakowski K., and Piechota T., 2015. Energy conversion from biomass to hydrogen and methane. 4th Int. Conf. Materials Engineering for Advanced Technologies (ICMEAT 2015), June 27-28, 2015, London, UK.

Czekała W., Pilarski K., Dach J., Janczak D. ,and Szymańska M., 2012. Analysis of management possibilities for digestate from biogas plant. Technika Rolnicza Ogrodnicza Leśna, 4, 13-15.

Dach J., Boniecki P., Przybył J., Janczak D., Lewicki A., Czekała W., Witaszek K., Rodriguez Carmona P.C., and Cieślik M., 2014. Energetic efficiency analysis of the agricultural biogas plant in $250 \mathrm{~kW}(\mathrm{e})$ experimental installation. Energy, 69, 34-38.

https://doi.org/10.1016/j.energy.2014.02.013

Energy Regulatory Office, 2018. Electricity selling price in 2017, https://www.ure.gov.pl/pl/stanowiska/7306, Informacja-nr-842017.html

Energy Regulatory Office, 2017. Yellow certificate price in 2018, https://www.ure.gov.pl/pl/stanowiska/7053, Informacja-nr-362017.htm

Gu Y., Zhang Y.L., and Zhou X.F., 2015. Effect of $\mathrm{Ca}(\mathrm{OH})_{2}$ pretreatment on extruded rice straw anaerobic digestion. Bioresour. Technol., 196, 116-122. https://doi.org/10.1016/j.biortech.2015.07.004

Herkowiak M., Adamski M., Dworecki Z., Waliszewska B., Pilarski K., Witaszek K., Niedbala G., and Piekutowska
M. 2018. Analysis of the possibility of obtaining thermal energy from combustion of selected cereal straw species. J. Res. Appl. Agric. Eng., 63(4), 68-72.

Hjorth M., Gränitz K., Adamsen A.P.S., and Møller H.B., 2011. Extrusion as a pretreatment to increase biogas production. Bioresour. Technol., 102(8), 4989-4994. https://doi.org/10.1016/j.biortech.2010.11.128

Igliński B., Buczkowski R., Iglińska A., Cichosz M., Piechota G., and Kujawski W., 2012. Agricultural biogas plants in Poland: investment process, economic and environmental aspects, biogas potential. Renew Sustain Energy Rev., 16(7), 4890-4900. https://doi.org/10.1016/j.rser.2012.04.037

Irlbeck N.A., Russell J.R., Hallauer A.R., and Buxton D.R., 1993. Nutritive value and ensiling characteristics of maize stover as influenced by hybrid maturity and generation, plant density and harvest date. Animal Feed Sci. Technol., 41(1), 51-64. https://doi.org/10.1016/0377-8401(93)90094-z

Karunanithy C. and Muthukumarappan K., 2010. Influence of extruder temperature and screw speed on pretreatment of corn stover while varying enzymes and their ratios. Appl. Biochem. Biotechnol., 162(1), 264-279. https://doi.org/10.1007/s12010-009-8757-y

Kołodziej B. and Matyka M., 2010. Renewable energy sources - agricultural energy resources (in Polish). PWRiL, Poznań,.

Kratky L. and Jirout T., 2015. The effect of process parameters during the thermal-expansionary pretreatment of wheat straw on hydrolysate quality and on biogas yield. Renew. Energy, 77, 250-258.

https://doi.org/10.1016/j.renene.2014.12.026

Lamsal B., Yoo J., Brijwani K., and Alavi S., 2010. Extrusion as a thermo-mechanical pre-treatment for lignocellulosic ethanol. Biomass Bioenergy, 34(12), 1703-1710. https://doi.org/10.1016/j.biombioe.2010.06.009

Lehmann Maschinenbau, 2012. Bio-extrusion. http://www.lehmann-maschinenbau.de/en/biogas-technology/ bio-extrusion.html

Lewicki A., Dach J., Czekała W., Janczak D., Cieślik M., Witaszek M., and Carmona P.C.R., 2014. Testing the biogas substrate efficiency from the Experimental Farm of Poznan University of Life Sciences in Przybroda biogas plant. Archives of Waste Management and Environmental Protection, 16(1), 27-30.

Li J.H., Zhang R.H., Siddhu M.A.H., He Y.F., Wang W., Li Y.Q., Chen C., and Liu G.Q., 2015. Enhancing methane production of corn stover through a novel way: Sequent pretreatment of potassium hydroxide and steam explosion. Bioresour. Technol., 181, 345-350.

https://doi.org/10.1016/j.biortech.2015.01.050

Liu X.Y., Zicari S.M., Liu G.Q., Li Y.Q., and Zhang R.H., 2015. Pretreatment of wheat straw with potassium hydroxide for increasing enzymatic and microbial degradability. Bioresour. Technol., 185, 150-157. https://doi.org/10.1016/j.biortech.2015.02.047

Mani S., Tabil L.G., and Sokhansanj S., 2004. Grinding performance and physical properties of wheat and barley straws, corn stover and switchgrass. Biomass Bioenergy, 27(4), 339-352. https://doi.org/10.1016/j.biombioe.2004.03.007

McKendry P., 2002. Energy production from biomass (part 1): overview of biomass. Biores. Technol., 83(1), 37-46. https://doi.org/10.1016/s0960-8524(01)00118-3 
Mesarić P. and Krajcar S., 2015. Home demand side management integrated with electric vehicles and renewable energy sources. Energy Buildings, 108, 1-9. https://doi.org/10.1016/j.enbuild.2015.09.001

Mo Z. and Pilarski K., 2011. Preliminary comparison of biogas productivity from maize silage and maize straw silage. J. Res. Appl. Agric. Eng., 56(2), 108-110.

Mosier N., Wyman C., Dale B., Elander R., Lee Y.Y., Holtzapple M., and Ladisch M., 2005. Features of promising technologies for pretreatment of lignocellulosic biomass. Bioresour. Technol., 96, 673-686. https://doi.org/10.1016/j.biortech.2004.06.025

Oleszek M., Tys J., Więcek D., Król A., and Kuna J., 2016. The possibility of meeting greenhouse energy and $\mathrm{CO}_{2}$ demands through utilisation of cucumber and tomato residues. BioEnergy Res., 9(2), 624-632. https://doi.org/10.1007/s12155-015-9705-Z

Papadias D., Ahmed S., and Kumar R., 2012. Fuel quality issues with biogas energy - an economic analysis for a stationary fuel cell system. Energy, 44, 257-277. https://doi.org/10.1016/j.energy.2012.06.031

Papurello D., Lanzini A., Tognana L., Silvestri S., and Santarelli M., 2015. Waste to energy: exploitation of biogas from organic waste in a $500 \mathrm{Wel}$ solid oxide fuel cell (SOFC) stack. Energy, 85, 145-158. https://doi.org/10.1016/j.energy.2015.03.093

Piwowar A., Dzikuć M., and Adamczyk J., 2016. Agricultural biogas plants in Poland - selected technological, market and environmental aspects. Renewable and Sustainable Energy Reviews 58, 69-74. https://doi.org/10.1016/j.rser.2015.12.153

Polish Power Exchange, 2017. TGE monthly market reports for 2017: December. https://tge.pl/en/538/raporty-miesiecznetge-sa-za-rok-2017

Przybył J., Wojcieszak D., Mioduszewska N., and Durczak K., 2013. Biogas yield of maize straw. Agric. Eng., 4(148), 103-111.

Rafique R., Poulsen T.G., Nizami A.S., Murphy J.D., and Kiely G., 2010. Effect of thermal, chemical and thermochemical pre-treatments to enhance methane production. Energy, 35(12), 4556-4561. https://doi.org/10.1016/j.energy.2010.07.011

Reilly M., Dinsdale R., and Guwy A., 2015. Enhanced biomethane potential from wheat straw by low temperature alkaline calcium hydroxide pre-treatment. Bioresour. Technol., 189, 258-265. https://doi.org/10.1016/j.biortech.2015.03.150

Rodriguez C., Alaswad A., Benyounis K.Y., and Olabi A.G., 2017. Pretreatment techniques used in biogas production from grass. Renewable and Sustainable Energy Reviews, 68(2), 1193-1204. https://doi.org/10.1016/j.rser.2016.02.022
Ruffino B., Campo G., Genon G., Lorenzi E., Novarino D., Scibilia G., and Zanetti M., 2015. Improvement of anaerobic digestion of sewage sludge in a wastewater treatment plant by means of mechanical and thermal pre-treatments: performance, energy and economical assessment. Bioresour. Technol., 175, 298-308. https://doi.org/10.1016/j.biortech.2014.10.071

Russell J.R., 1986. Influence of harvest date on the nutritive value and ensiling characteristics of maize stover. Animal Feed Sci. Technol., 14(1-2), 11-27. https://doi.org/10.1016/0377-8401(86)90003-9

Shaefer H., 1994. VDI-Lexikon Energietechnik. Springer-Verlag Berlin Heidelberg.

Tedesco S., Benyounis K.Y., and Olabi A.G., 2016. Mechanical pretreatment effects on macroalgae-derived biogas production in co-digestion with sludge in Ireland. Energy 61, 27-33. https://doi.org/10.1016/j.energy.2013.01.071

Theuretzbacher F., Blomqvist J., Lizasoain J., Klietz L., Potthast A., Horn S.J., Nilsen P.J., Gronauer A., Passoth V., and Bauer A., 2015a. The effect of a combined biological and thermo-mechanical pretreatment of wheat straw on energy yields in coupled ethanol and methane generation. Bioresour. Technol., 194, 7-13.

https://doi.org/10.1016/j.biortech.2015.06.093

Theuretzbacher F., Lizasoain J., Lefever C., Saylor M.K., Enguidanos R., Weran N., Gronauer A., and Bauer A., 2015b. Steam explosion pretreatment of wheat straw to improve methane yields: investigation of the degradation kinetics of structural compounds during anaerobic digestion. Bioresour. Technol., 179, 299-305.

https://doi.org/10.1016/j.biortech.2014.12.008

White E.M., Latta G., Alig R.J., Skog K.E., and Adams D.M., 2013. Biomass production from the U.S. forest and agriculture sectors in support of a renewable electricity standard. Energy Policy, 58, 64-74.

https://doi.org/10.1016/j.enpol.2013.02.029

Zhang Q., Hu J., and Lee D.J., 2016. Biogas from anaerobic digestion processes: Research updates. Renewable Energy, 98, 108-119. https://doi.org/10.1016/j.renene.2016.02.029

Zhang X., Ruoshui W., Molin H., and Martinot E., 2010. A study of the role played by renewable energies in China's sustainable energy supply. Energy, 35, 4392-4399. https://doi.org/10.1016/j.energy.2009.05.030

Zheng Y., Zhao J., Xu F., and Li Y., 2014. Pretreatment of lignocellulosic biomass for enhanced biogas production. Progress in Energy and Combustion Science, 42, 35-53. https://doi.org/10.1016/j.pecs.2014.01.001 